\title{
EU NETWORK CARRIERS, LOW COST CARRIERS AND CONSUMER BEHAVIOUR: A DELPHI STUDY OF FUTURE TRENDS
}

\author{
Keith J Mason $^{\mathrm{a}}$ and F. Alamdari ${ }^{\mathrm{b}}$ \\ a - Department of Air Transport, Cranfield University, Bedfordshire, MK43 0AL, UK., \\ K.Mason@cranfield.ac.uk \\ b - Boeing Commercial Airplanes, PO Box 3707 MC 21- 30, Seattle, WA 98124-2207, \\ USA., Fariba.Alamdari@Boeing.com
}

\section{ABSTRACT}

This paper uses a Delphi panel of 26 air transport experts to forecast the structure of air transport in the EU in 2015 in respect of network carriers, low cost airlines and passenger behaviour. Secondary research was used to construct a number of scenarios about the future structure and strategy of EU network and low cost airlines and also traveller behaviour. Consensus of opinions was sought amongst the panel in a two-round process. The consensus opinion of the Delphi experts was that; network carrier consolidation will reduce EU players to less than five, there will be only 2 - 3 large LCCs, Business Class products will disappear on short hauls, and leisure travellers will take an increasing number of multiple short-duration holidays.

KEYWORDS: Network airlines, low cost carriers, traveller behaviour, Delphi technique 


\section{Introduction}

The purpose of this study, funded by the European Commission was to identify future trends in the European air transport sector over the next 10-15 years. While the full European Commission study covered many aspects of "Aviation in the EU" (European Commission, 2005), this paper focuses on EU network and low cost carriers and also changes in consumer demand for air transport. The paper uses published literature to examine and establish the current position with respect of network and low cost carriers and consumer demand. This analysis is then used to develop possible future market scenarios. The likelihood of these scenarios coming into reality was then examined using a two stage Delphi survey of aviation experts.

\section{EU Air Transport in the first five years of the 21st Century}

The major part of the European airline industry was in difficulty before the traumatic events of September $11^{\text {th }} 2001$. A number of factors had started to impact adversely on the industry's financial fortunes from 2000 onwards. A slowing down in key economies, such as those of Germany and Japan, as well as several more in Europe led to a slowing in traffic growth. The collapse of the dot.com boom undermined business confidence which in turn impacted the demand for business travel. At the same time in many long-haul markets 
overcapacity was becoming a serious problem. This overcapacity and the very rapid growth of low-cost operators, especially in intra-European markets, were creating strong downward pressure on average fares and yields. Yet costs were rising. Between October 1998 and October 2000 fuel prices doubled, while labour costs were rising as new wage agreements were negotiated in the aftermath of the very profitable years of 1995 to 1999.

The events of September 2001 turned a growing crisis into disaster as traffic levels in many key markets collapsed, more especially on the North Atlantic. Sabena and Swissair filed for bankruptcy. Most of Europe's scheduled airlines posted large losses or severely diminished profits for 2001. Only the large low-cost carriers, Ryanair and easyJet, bucked the trend by showing increased profits.

The invasion of Iraq early in 2003, followed by the SARS epidemic in the Far East, hit Middle East and Asian routes. But as traffic growth started to accelerate again in 2004, a new challenge, the rapid rise in fuel prices began to undermine airline profitability once more. Against this turbulent and unstable market environment since 2000 the financial performance of Europe's airlines was varied.

\section{Network airlines}


The position of the top ten EU airlines, in relation to their share of total Available Seat Kilometres (ASK) and departures within the EU in 2004, is illustrated in Table 1. Clearly, British Airways, Lufthansa and Air France are the principal carriers in the EU market. These three carriers are responsible for over half the total ASK and over $40 \%$ of weekly flights operated by the EU network airlines. If KLM's operation is added to that its owner, Air France, $61 \%$ of ASK and $47 \%$ of departures are performed by the top three carriers. The rest of EU airlines offer much smaller shares of total capacity.

\section{\{TABLE 1 ABOUT HERE\}}

Figure 1 illustrates the financial performance of EU airlines. It is of interest to note that EU airlines have always struggled to make any profits on intra-European routes, however their operations on these routes have been vital to feed traffic onto their more profitable long haul routes. The profitability of European operations is a major issue for all EU network carriers, especially in recent years when they have faced very tough competition from the low costs carriers. The profitability of long haul routes has encouraged carriers to focus on these types of routes in order to improve profitability.

\{FIGURE 1 ABOUT HERE\}

Figure 2 illustrates the EU airlines intra-European RPK as a percentage of their total operations. While carriers such as KLM, British Airways and Air France are less dependent on intra-European traffic, others such as Luxair and Air Malta have been mainly operating 
on intra-European routes. Clearly, this latter group of carriers are more exposed to the threat of low cost airline competition than others.

\{FIGURE 2 ABOUT HERE\}

Analysis of EU operations by airline shows that while the largest carriers (measured by ASK) have increased capacity at a lower rate, and in some cases they have made cut-backs, the smaller operators have increased their capacity at a higher rate. For example, over the five year period, 1999-2004, British Airways, Lufthansa and Air France have increased their ASK by an average annual rate of $1 \%, 6 \%$ and $4 \%$ respectively while the number of departures have changed by $-2 \%, 2 \%$ and $4 \%$ (OAG, 1999 and OAG, 2004). Over the same period, Austrian and Spanair increased their ASK at an average rate of 14\% and 9\% each year and departures at a rate of $20 \%$ and $17 \%$. It is noticeable that the large East European airlines, LOT, Malev and Czech have been adding flights at an average rate of $10 \%$ to $13 \%$ per year.

\section{Low cost carriers}

The low cost airline sector in Europe has grown dramatically since Ryanair first started operating as a low cost carrier (LCC) in 1991, and easyJet established in 1995. The 9/11 terrorist attacks acted as a catalyst for a dramatic change in the structure of the UK airline 
industry. While British Airways maintained short haul business fares and reduced capacity for leisure travellers, easyJet and Ryanair reduced their fares and built capacity. EasyJet in particular took BA's capacity reduction at Gatwick as an invitation to establish a base at London's second airport.

In 2002 and 2004, as the UK market began to become crowded following the arrival of Buzz, bmibaby, MyTravelLite and Jet2, among others, consolidation occurred as easyJet bought out BA's subsidiary Go and Ryanair purchased KLM's subsidiary Buzz. Continental Europe is following suit with a rapid burst of high market growth, which is expected to be followed by a levelling off and consolidation. Indeed, according to Credit Suisse First Boston, LCCs in 2004 accounted for $20 \%$ of European airline passengers, and 43\% of the domestic UK market (Travel Weekly, 2004).

LCC passenger traffic is estimated to have totalled 94.6 million in 2004. Table 2 shows the 10 largest European LCCs in terms of available seat-kms in June 2004. EasyJet and Ryanair are, by some degree, the largest LCCs in Europe but Air Berlin is not far behind in size. Air Berlin still operates a considerable number of charter/leisure flights, which are included in the table.

\{TABLE 2 ABOUT HERE\}

Figure 3 shows the percentage of scheduled seats on domestic and intra-EU routes provided by LCCs for each of the original 15 Member States.

\{FIGURE 3 ABOUT HERE\} 
The addition of ten countries to the European Union has meant that there has been a lot of activity in the accession countries as LCCs look to establish a presence, while a number of home country start-ups have looked to gain entry into the market (including Wizz Air in Poland and SkyEurope in Slovakia and Hungary). By the summer of 2004 the LCC sector had grown in number to around 50 airlines, according to the European Low Fares Airline Association (Airline Business, 2004). However, aside from easyJet and Ryanair most LCCs were either loss making or generating only very marginal levels of profit. LCCs not operating profitably in 2004 included Hapag Lloyd Express, Norwegian, Sterling, Thomsonfly and Virgin Express. Germanwings claimed to have reached break-even in 2004, while Air Berlin earned a profit of less than 10 million euros on a turnover of 1.05 billion euros.

\section{Key changes in passenger behaviour}

Economic growth, business confidence, people's desire to travel and price are the key drivers of demand for air travel. The increase in globalisation and freedom of movement of people and goods within and between regions, are positive factors affecting demand. 
It appears that leisure travel is growing faster than business travel. For example, Table 3 shows leisure travel into and out of six principal UK airports to a number of European countries growing more quickly than business travel. In 1996 the leisure market represented $55.8 \%$ of the passengers, however over the seven year period leisure travel grew more quickly (at $9.4 \%$ pa) than business travel (just $2.5 \%$ pa) and by 2003 the leisure market represented $66.6 \%$ of the market.

\section{\{TABLE 3 ABOUT HERE $\}$}

These changes in market structure are mainly attributable to the growth of the low cost carrier sector which has led to a fall in yield. Changes in both the business travel and leisure markets will be considered below.

\section{The business travel market}

The business travel market has seen a marked change in recent years but remains vital to the airline industry. The airline industry has long relied on the business travel market as a major source of profit. Although only $15 \%$ of the IATA airlines' capacity is allocated to Business Class, it generates $28 \%$ of revenue. More importantly, the operating profit margin from Business Class in 2002 was 29\% compared to just 5\% from Economy Class (IATA, 2003). 
From 2000 onwards, however, the proportion of travellers using Business Class has been falling. A decline in the take up of business class tickets and increased downgrading behaviour has shown that the business market does display price elasticity. This has been particularly evident in the short haul market with the arrival of low cost airlines. Figure 4 illustrates the decline in business passengers travelling in business class on a number of European airlines. British Airways forecasts that as few as $15 \%$ of short haul business trips will be taken in business class by 2006 (Sentance, 2003).

\section{\{FIGURE 4 ABOUT HERE\}}

The industry is coming to terms with the fact that a large proportion of passengers have chosen price over service (e.g. frills, choice or flexibility). As short haul business travel in Business Class has fallen, a survey by Company Barclaycard shows that the proportion of business passengers that have used low cost carriers for business trips has risen to $71 \%$ in 2004/5 compared to just 28\% in 1998/9 (see Table 4, Company Barclaycard, 2004/5). This is due not only lower fares but the fact that business passengers have more choice of business destinations by low cost airlines.

\section{\{TABLE 4 ABOUT HERE $\}$}

IATA's Corporate Air Travel Survey (IATA 2004) shows (Figure 5) that price has become the principal determinant for short haul business travellers with FFP points and convenient schedule being next most important. 
\{FIGURE 5 ABOUT HERE\}

For long haul travel, seat comfort, price and FFP seem to be the principal purchase factors, although price would seem to be relatively less important than for short haul travel.

Satellite and electronic communication technology can be seen as having both a generation and substitution impact on the demand for business travel. The ability provided by technology to communicate effectively with business partners and customers anywhere in the world can be seen as leading to a growth in business travel as executives travel increasingly far afield to conduct business. In this way communication technology can be seen as a travel generator. However the ability to conduct business effectively with IP based technologies like web-casting and file sharing office suites, and video- and teleconferencing may suppress the need to travel for business. Face-to-face sales meetings are unlikely to be easily substituted by electronic communication, whereas internal project meetings are more likely to be able to be conducted online.

\section{The leisure travel market}

Europeans tend to enjoy long paid annual leave (see Table 5) Although there is some variation in leave entitlements among states, with those in Western Europe tending to enjoy more generous holiday provision than their neighbours in the East, a large proportion of the population in all of them take advantage of their holiday entitlement. This should certainly have a positive impact on air travel within and from Europe. 
\{TABLE 5 ABOUT HERE $\}$

In recent years there has been a trend towards a greater number of shorter trips by European travellers. Traditionally, a single long holiday each year was the norm. However, there seems to be a growing trend to split the annual holidays and take shorter breaks. Table 6 illustrates the annual growth rate in the number of short and long holidays. It can be seen that short breaks are increasingly popular in the majority of the European countries in the sample.

\section{\{TABLE 6 ABOUT HERE\}}

In recent years there has been a greater growth in travel within Europe than to countries outside Europe. For example, in 2003, traffic from UK to Europe increased by $8.9 \%$ compared to $2.5 \%$ on long haul trips. This compares with an annul growth rate of $7.3 \%$ to Europe and 6.9\% on long haul between 1993 and 2000. The slow growth in traffic on long haul routes could be due to concerns about health (e.g. SARS, DVT), terrorism and security in recent years.

The internet has had a profound impact on the way consumers search for and book their holidays. The fact that the majority of bookings with low cost airlines are made through the internet has led to the growth in popularity of this channel, and in turn has made 
comparison of airline prices much easier. This is one of the contributory factors to the decline in airline average prices. The trend in leisure passengers indicates that they expect and will continue to expect low fares. Low fares have been the main stimulus for growth in leisure travel, with leisure passengers being prepared to switch destination for good deals.

\section{Research scenarios}

Following this brief review the following scenarios were constructed to be assessed in a Delphi survey of air transport industry experts:-

- The largest network carriers will come to dominate the European airline industry by a combination of natural growth, alliances, and merger and acquisition activity

- Smaller network carriers will need to find defensible niche roles or are likely to reduce in importance or be subsumed within the networks of the dominant European carriers

- Network carriers will address the fundamentally poor economics of short haul feeder services into hubs by increasingly using franchised feeder services and partners

- In long haul markets, business travellers will increasingly put higher value on business class services 
- In short haul markets business class products will disappear as an insufficient number of business travellers are prepared to pay for them.

- As technology continues to improve, business travellers will increasingly embrace web and video based conferencing solutions to substitute for some business trips

- Growth in long haul leisure travel destinations will grow faster than short haul destinations

- Leisure trips will get of increasingly shorter duration.

\section{Methodology}

To forecast the EU air transport market of 2015 a Delphi study was conducted with experts within the EU air transport field.

The Delphi study technique is a communication structure aimed at producing detailed critical examination and discussion of issues. Developed in the 1950s and 60s by the Rand Corporation, the technique was designed to elicit the opinions of experts in a particular field in a systematic way (Sackman, 1974). It has been described as a "succession of 
iterative brainstorming rounds" (Jantsch, 1967), and is well suited to forecasting complex problems and is an excellent tool for gaining input from recognised sources of expertise.

Linstone and Turoff (1975) note that at the outset the technique was used mainly for technological forecasting, however it has been applied across a number of fields of research including economics, operational research, philosophy, psychology, sociology and statistics. Examples of research problems that the Delphi technique has been applied to include; marketing expenditure effectiveness (Kotler, 1970), the demand for telephony (Day, 1973), forecasting economic conditions (Decker, 1974), and political science (Pavitt, 1972).

The Delphi method involves the recruitment of a number of field "experts" and uses an iterative process to attempt to reach consensual forecasts. The experts and their contributions are anonymous so that each expert's view is given considered equally. The process involves collecting answers to a number of questions posed to each of the experts. In the first round each expert is expected to provide an answer to each question and also a justification for their answer along with any assumptions made. The research team then distil the answers and feedback a summary of the responses and justifications with the entire group. In the second round, the experts then consider the strength of the various answers and re-assess their own answers. In this way over a number of iterations it is likely that the views of the experts will coalesce and a degree of consensus will be achieved. 
The Delphi approach enables the communication between panel members of diverse and potential divergent opinions. The technique reaps the benefits of group decision making while insulating the process from the limitations of group decision-making and undesirable interaction effects; e.g., over-dominant group members, lobbying, or "bandwagonism" (Cline, 2000). While there are some clear advantages with the approach, conducting a Delphi study can be very time consuming. The requirement of the experts to spend time to describe their views and to provide supporting arguments, the requirement of the research team to distil the submissions of the experts at the end of each round, and the iterative nature of the approach means that the whole process can take many months. Computer based elicitation of answers, particularly where experts are dispersed geographically, can reduce the time taken to collect answers. However, persuading experts in their field to spend time completing repeated rounds of surveys can be difficult. Linstone and Turoff (1975) summarise eight pitfalls that can befall a Delphi study including the tendency for forecasters to use a sub-conscious discounting rate in their calculations, to simplify the complex and to rely on panel experts that do not have a wide view of system being considered. They also note the potential to come to erroneous conclusions due to the process of making respondents anonymous. Where a particularly insightful expert has a opinion that opposes the majority of the panel this, perhaps accurate forecast, may be lost as other panellists coalesce around the alternative view (Linstone and Turoff, 1975).

For this study a number of key air transport industry experts were invited to participate in the Delphi panel. Sixty-one industry experts working in senior roles for airlines (network, 
LCC, regional, cargo, and leisure), airports, civil aviation authorities, industry associations, consultancies were contacted by email with an invitation to participate in the panel.

A questionnaire for the first round of the survey was developed. Statements on which the panel were to comment were developed by the research team which included eight faculty members of the Department of Air Transport at Cranfield University (The authors would like to recognise the participation of P. Morrell, R. Pagliari, I. Stockman, A. Foster, G. Williams, and R. Fewings) and Visiting Professor Rigas Doganis. The developed survey was then sent to industry experts, Andrew Hofton and Chris Tarry to ensure the content validity of the questionnaire, and that the instructions for the participants were unambiguous. Panellists were informed that they would be required to complete two self completion surveys, the first of which was included with the email. Participants had the option of completing the survey online, or by printing the survey and returning their hand written responses.

The first round questionnaire contained 27 statements which respondents asked whether they agreed or disagreed with (respondents could also indicate that they had "no opinion" about a particular statement). Respondents were also asked to provide comments on the reasons for the answer given, and to indicate the strength with which respondents held their views. In this way the veracity of the statements in the survey could be examined and thereby test various hypotheses about the future of air transport in the EU. The Delphi technique seeks to establish where the panel is in broad agreement on a particular issue. For the purpose of this study, it was decided that if three quarters or more 
of the respondents were in agreement on a particular topic consensus was broadly reached. Where consensus on a topic was not found then the comments provided by the panel was used to understanding the reasons for the division in opinion. In these cases new questions that drew on the comments given in the first round were written and used in a second round survey of the panel members. Again $75 \%$ agreement in the second round survey was used as a "broad consensus" threshold

The approach to ask respondents to rate the strength of their views has been used in a number of Delphi Studies (e.g. Ludlow, 1975, Hamoen, 1998, Hummel, 2002). In this study respondents were asked to rate the strength of their view on a five point Likert style scale with a score of 5 being "Very strongly held view" to 1 equal to a "Very weakly held view". To assess the strength with which the majority held their view, the average score was calculated and presented in the findings. The higher the score for strength of view the greater the confidence the researchers had in the veracity of the majority expert view.

\section{Results}

Twenty-six of the group of experts invited to join the Delphi panel responded to the first survey stage. This represents a response rate of $43 \%$. In some studies where the panel is highly concerned with the subject area a very high response rate has been achieved. For example in a small study of proactive contracting in US Air Force a response rate of $87 \%$ in 
a panel of 15 was achieved (Wellman, 2003) where as in studies where the experts are drawn from a larger group and the interest in the findings of the report are less directly related to the experts the response rate is unsurprisingly lower. For example in a study of drug-abuse policy (Jillson, 1975), forty-five experts were invited to participate and twentyfive completed the two rounds (55\%). In this case the importance of the study to the experts would be limited as the results would have little commercial value to the participants thereby reducing the likely response rate. Delbecq et al (1975) suggest that the panel size of a homogeneous group of ten to fifteen participants is adequate. Given that all respondents were working in the air transport industry it was felt the sample was sufficient.

The panel reached consensus on 11 of the 27 statements in this first round. Where consensus was not reached, the written opinions and the strength of the confidence in the replies given, were used to develop new statements more likely to attain a consensual view. A statement in the first survey was somewhat ambiguous, and this was split into two separate statements for the second round. Consequently a second stage survey with 14 new statements was sent to the panel of 25 respondents for completion. In the second stage consensus was once again defined $75 \%$ agreement.

\section{Network carriers}


Table 7 shows the results of the first stage of the Delphi study concerning network carriers. These are the statements for which consensus were reached. The results show broad consensus to the view that the difficulty network carriers face in short haul markets will mean that these carriers will increasingly focus on longer haul markets, and use franchise or small alliance partners to feed their long haul networks.

\section{\{TABLE 7 ABOUT HERE $\}$}

Another scenario proposed to the Delphi panel suggested that as network carriers will never be able to achieve the cost structures of the low cost carriers in their short haul markets, network carriers will increasingly focus on long haul markets where they can derive sustainable profit streams. The network carriers will pull out of a significant proportion of their short haul markets, remaining in only very large short haul markets or on routes where there is large proportion of business travellers. The network carriers will increase their use of smaller airlines to feed their long haul routes. The feeder airlines may be niche/regional airlines that have cost structures that are suited to this role. A large proportion of Delphi expert agreed that large network carriers will increasingly migrate to long haul routes, and they will make greater use of franchisee or smaller alliance partners in feeding traffic to their long haul services.

Although focusing on long haul routes could increase the opportunity to serve more high yielding passengers, it can lead to over capacity and lower yields as more network carriers, especially those from the US, turn their attention to long haul routes. Similarly, the 
expansion of the Gulf area airlines could be a threat to EU airlines, especially on long haul routes to the Gulf and beyond. As discussed before airlines from Middle East sub-region have ordered the largest number of wide body aircraft to be delivered over the next 10 years, including the 51 Airbus A380s ordered by Emirates, Etihad and Qatar Airways combined. A large majority of respondent experts agreed that such scenarios will be the nature of competition in the future. Given that some of the Gulf area airlines are very well positioned in their markets, they could compete fiercely with the EU airlines. At the same time, it would not be surprising to witness even more intense competition on North Atlantic routes leading to further overcapacity and lower yields.

In the second stage consensus was reached in five of the nine new statements. As network carriers face up to the poor economics of bringing short haul feed traffic into hubs with small originating markets, there will be fewer main hubs in the EU. A very large proportion of experts believe that hub and spoke operations are here to stay as an important component of inter-continental travel. However, these hubs will lose their degree of importance as more flights will by-pass hubs in response to increasing demand for non stop services.

Recent trends in large airline partnerships and alliances and the economics of the industry helped formulate a scenario where the network carrier market in the EU will consolidate considerably in the next ten years through merger and acquisition (and airline failures) resulting in between three and five dominant network carriers. Replies to the Delphi survey indicate that the group of experts strongly agreed that in the next 10 to 15 years no more 
than five large EU based airlines will be around. It was noted that such a trend has already started with the merger of Air France and KLM, the potential take over of Swiss by Lufthansa and the close collaboration between British Airways and Iberia.

\{TABLE 8 ABOUT HERE\}

On the subject of network carriers establishing low-cost subsidiaries, the general belief expressed by the panel is that although this has been employed as a strategy to combat low cost airlines, it is unlikely to succeed. It could be used as a short term tactic until the "parent" airline can lower its cost base.

As the airline network market becomes increasingly dominated by a few large players, smaller network carriers will face acquisition or failure leading to only two or three medium sized airlines surviving. The experts rejected this idea believing that these airlines will carry on by focusing on niche markets. They also rejected the idea that these airlines will focus on feeding traffic to large network carriers. However, they agreed that medium size airlines will increasingly adopt low cost business models as this is the only way to ensure survival.

The experts could not agree on the number of cabins required in long haul fleets. A number of respondents believed that the three-class service is here to stay but it will be business, 
premium economy and economy rather than first, business and economy. On the issue of EU airlines offering unbundled products, with each element sold separately, there was a complete division among the respondents.

High speed rail services will be viable alternatives to short-haul point-to-point air links. But where these services connect with the air transport network through integrated airport rail-stations, there is an opportunity for cooperation, particularly through the provision of rail-based feeder services. The two developments, competition and cooperation, are not mutually exclusive and this was reflected in replies from the Delphi panel. Members were pretty evenly split on the question of competion or complementarity. Some pointed out the value of cooperation in freeing capacity at airports, but others cited the success of highspeed rail in competing on short-haul intercity routes. A number identified as crucial the provision of fully integrated airport/railway interchange stations if rail is to be a feeder of air transport network.

Another area where the experts did not reach a consensus was that of trade union collaboration with airline management. Half the respondents hoped that this would be the case, but the rest disagreed on the basis that the pressure on airlines to make profit would negatively affects job numbers and wages, leading to potential conflict between management and employees. 


\section{Low cost}

The Delphi panel were of the opinion that the while the low cost sector is likely to capture a very significant share of the intra-EU market not all low cost carriers will prosper.

\section{\{TABLE 9 ABOUT HERE\}}

The two statements that the panel agreed with in the first round of the survey was that more than half of intra-EU traffic would be carried by low cost carriers by 2015 and that there will only be two or three large LCCs.

The forecast of the size of the market is broadly in line with other studies that have forecast the future size of the low cost carrier market, and how far the segment will penetrate the network carrier market. For example, the European Low Fares Airlines Association (ELFAA) forecasts that low cost traffic in Europe will be $40 \%$ of the market by $2010^{10}$, while TUI estimates the low cost sector to be $33 \%$ of the market in $2010^{11}$. However, the Delphi panel is of the view that the LCC share of the intra-EU market will be even larger than these other forecasts. When asked about EU policies to limit regional or airport subsidies, the view of the panel (in the second stage) was that the removal of any such aid would have only a minor impact on the growth of the market.

\footnotetext{
${ }^{10}$ Liberalisation of European Air Transport: The benefits of low fares airlines to consumers, airports, regions and the environment, ELFAA, 2004

${ }^{11}$ Wolfgang John, Trends in leisure travel: What holds for the future? $8^{\text {Th }}$ Hamburg Aviation Conference, Feb 2005
} 
The low cost segment has already seen a large proportion of failures and take-overs in the last couple of years. It is likely as the segment grows towards maturity throughout its European markets that there will be further consolidation. The Delphi panel thought that the sector will be dominated by a small number of large players. There seem to be significant economies of scale in the low cost sector. These include the potential for large discounts for significant aircraft purchase deals, maintenance and ground handling. There also seems to be first mover advantage in the market. We have seen the successful establishment of new bases of some very large low cost carriers in markets outside their home countries, while new start-ups are finding it increasingly difficult to enter markets where other low cost carriers have already established. This view is also supported by evidence from the US market where three carriers dominate the sector. As to the numbers of other LCCs in the market, the panel did not reach a consensus. More than $60 \%$ of the panel, however, did think that more than 10 smaller/niche carriers would exist in the market throughout the research period, although volatility in the market would mean the individual players are likely to change.

\section{\{TABLE 10 ABOUT HERE\}}

The Delphi panel, in the second stage, did not seem to think that as low cost carriers increase their network coverage they would enter into codesharing or interlining arrangements with network carriers. The reasons given were: the lack of slots at hub airports; the necessity of LCCs to breakaway from their normal model to enable such 
formal arrangements; and the fact that many LCCs prefer to fly to secondary airports. This would imply that in the future air transport market will have two quite separate systems: point to point short haul services mainly provided by LCCs; and interconnecting networks provided by traditional carriers.

The panel was split on whether LCCs would introduce facilitated online connections. This is a facility offered already by Southwest in the US and with a significant number of passengers "self-connecting" at the main bases for LCCs (e.g. Stansted) the networks of the large LCCs are becoming sufficiently large to warrant such a development in the EU market.

\section{Market behaviour}

The fall in value placed on short haul business class travel and large numbers of travellers downgrading to economy class tickets or using low cost carriers suggested that business class service in short haul markets are likely to be withdrawn. The Delphi panel were in broad agreement with this scenario, and therefore we conclude that by 2015 business class products will no longer available for intra-EU travel.

As video conferencing technology and other forms of web-based communication tools get increasingly sophisticated, it was felt that air travel, particularly for business related purposes may in someway be impacted. However, the panel were clear in their view that 
video-conferencing would not limit the growth of air travel within the time frame of the study. The written comments indicated that while this technology may reduce the demand for some trips, the availability of such communication devices would lead to traffic generation which would either outstrip the substitution effect or be at least neutral.

The desk research highlighted the growth in shorter-duration holidays. The panel were in near total consensus when considering this issue. The results show that the panel believes the trend towards a greater number of, shorter-duration holidays will continue throughout the study period.

\section{\{TABLE 11 ABOUT HERE $\}$}

The desk research noted the establishment of business class only services on some long haul routes. In the first stage of the survey the panel were asked whether such services would become "commonplace". The comments indicated that this was unlikely and that such services were more likely to develop in some niche markets. The revised statement used in the second stage of the Delphi study asked whether such services were likely to succeed but only in a "limited number of inter-continental routes". The panel strongly agreed with the revised statement indicating that the future market is likely to see such services continue and perhaps grow, but they will only operate in a fairly small number of markets. One respondent thought these are likely to be 'the trunk routes only, where the volumes will allow for the level of schedule to make the product a realistic \& consistent business choice for passengers'. 
Regarding the growth of long haul holiday markets, the panel once again did not reach consensus. Most panellists thought that the market would grow more quickly than the short haul holiday market (but from a significantly lower base), but prices, exchange rates, and the availability of low cost flights to short haul destinations were all noted as issues that impact long haul's comparatively higher growth rate over short haul holidays.

\section{\{TABLE 12 ABOUT HERE\}}

\section{Conclusions}

The purpose of this study was to assess the elements affecting the market structure and financial viability of European air transport over the next 10-15 years. A Delphi study approach was a suitable method drawing together the views of industry experts to assess veracity of hypotheses about how network carriers, low cost carriers and airline customers in the forecast time frame. The results of the Delphi experts suggest that business travellers will increasingly seek better value for money leading to the end of business class services in short haul markets and leisure travellers taking advantage of low fares to vacation more frequently both in the EU and further abroad. The airline market is likely to consolidate into a small number of very large network carriers and a similarly small number 
of very large low cost carriers. The surviving low cost carriers will prosper and eventually carry about half of intra-EU traffic. Feeder services into main hub airports will increasingly be operated by lower cost based franchised partner airlines. There will continue to be an independent role for the small and medium sized European carries, by focusing on point-to-point markets, and feeding traffic to larger network airlines. Highspeed rail could also provide feed into hubs where the infrastructure allows that, but elsewhere is likely to compete with short haul air services. Competition for network carriers will continue to be intense on major long haul markets. Services to Gulf and beyond will become increasingly vulnerable to competition from Gulf area airlines due to their large expansion in capacity.

\section{References}

Airline Business, (2004), "Cost Conscious”, Airline Business, October, pp. 33 - 36.

Association of European Airlines, (2004), "Yearbook", Association of European Airlines, Brussels.

Cline, A., (2000), Prioritization using Delphi Technique, White Paper, Carolla Development, Carrolla.com

Day, L. H. (1973), “Long Term Planning in Bell Canada”, Long Range Planning, London, (Submitted for publication, 1973)

Decker, R. L. (1974), “A Delphi Survey of Economic Development”, Futures, No. 2, April. 
Delbecq, A. L. , and Van de Ven, A. H. and Gustafson, D.H. (1975), "Group Techniques for Program Planning: a guide to nominal froup and Delphi processes", Scott, Foresman and Co., USA.

European Commission, (2005) "A study on The Future of Air Transport in the European Union”, European Commission, TREN/F1/11-2004.

Association, Airline Economic Task Force, Montreal, December

Company Barclaycard, (1999 - 2004/5), "Business Travel Survey”, Company Barclaycard, London.

Euromonitor, (2004), country reports for Germany, France, UK, Spain, Italy, Czech Republic, Poland, Euromonitor.com.

Hamoen, F.A.M., (1998) "Combination carriers and a dedicated air cargo hub-and-spoke network", Unpublished MSc Thesis, University of Plymouth.

Hummel, F. (2002), "The effect of corporate involvement on the business travel market", Unpublished MSc Thesis, Cranfield University

Jantsch, E. (1967), “Technological Forecasting in Perspective”, OECD, Paris.

IATA, (2003), “Airline Economic Results and Prospects”, International Air Transport, Montreal.

IATA, (2004), “Corporate Air Travel Survey”, International Air Transport Association, Montreal.

IATA, (2005), "World of Air Transport Statistics", International Air Transport Association, Montreal. 
Jillson, I. (1975), “The National Drug-Abuse Policy Delphi: Progress Report and Finidings to Date”, in Linstone, H. and Turoff, M. (1975), “The Delphi Method: Techniques and Applications", Addison Wesley, USA.

Kotler, P. (1970), “A Guide to Gathering Expert Estimates: The Treatment of Unscientific Data”, Business Horizons, October, pp. 79 - 87.

Linstone, H. and Turoff, M. (1975), "The Delphi Method: Techniques and Applications", Addison Wesley, USA.

Ludlow, J. (1975), "Delphi Inquiries and Knowledge Utilization” in Linstone, H. and Turoff, M., “The Delphi Method: Techniques and Applications”, Addison Wesley Longman, USA.

OAG (1999), “Official Airlines Guide”, London, June.

OAG (2004), “Official Airlines Guide”, London, June.

OAG (2005), “Official Airlines Guide”, London, June.

Pavitt, K. (1972), “Analytical Techniques in Government Science Policy”, Futures, 4, No. 1, March.

Travel Weekly, "Low cost carriers to take $40 \%$ of market", Travel Weekly, London, 20/8/04

Sackman, H. (1974), "Delphi critique. Expert opinion, forecasting, and group process", Lexington, USA.

Sentance, A., (2003), "Growth and restructuring in the global airline industry", Presentation at Cranfield University, 7/10/203

Wellman, G. L. (2003), “A Delphi Expert Assessment of Proactive Contracting in an Evolutionary Acquisition Environment", Unpublished MSc, Air Force Institute of Technology, US Air University. 
Table 1: Largest EU Network airlines, by share of Network airline ASK

\begin{tabular}{lcc}
\hline Airline & \% total ASK (2004) & Accumulated \% \\
\hline British Airways & 20.4 & 20.4 \\
Lufthansa & 17.8 & 38.2 \\
Air France & 14.9 & 53.1 \\
KLM & 7.6 & 60.7 \\
Iberia & 6.8 & 67.5 \\
Alitalia & 4.9 & 72.4 \\
Virgin Atlantic & 4.0 & 76.5 \\
SAS & 3.8 & 80.3 \\
Swiss & 2.8 & 83.0 \\
Austrian & 2.8 & 85.8 \\
\hline
\end{tabular}

Source: OAG June 2004 
Figure 1: European network carriers net profit by regions, 1999 to 2003

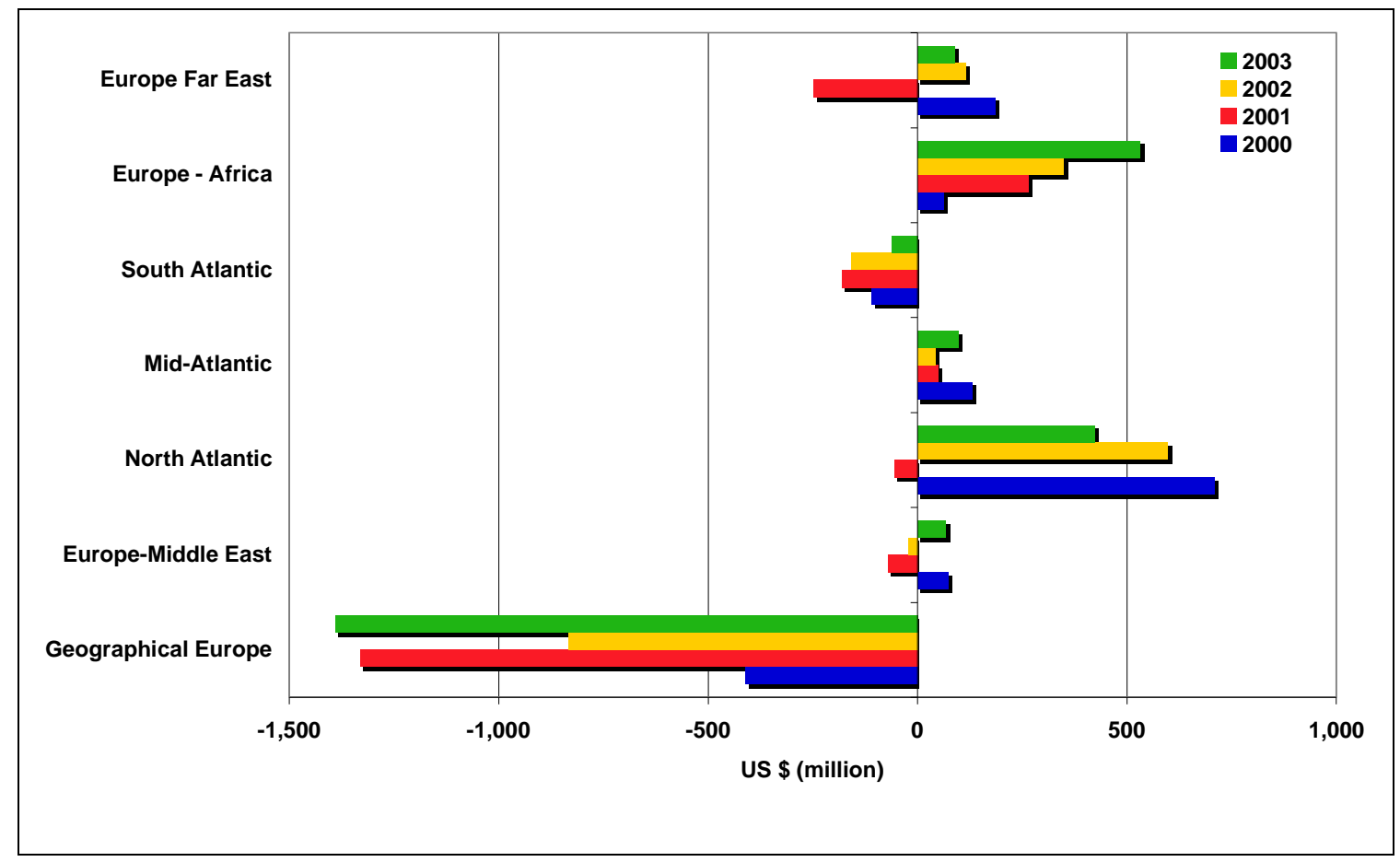

Source: Association of European Airlines, 2004 
Figure 2: EU airlines intra-European RPK as \% of total operations (2004)

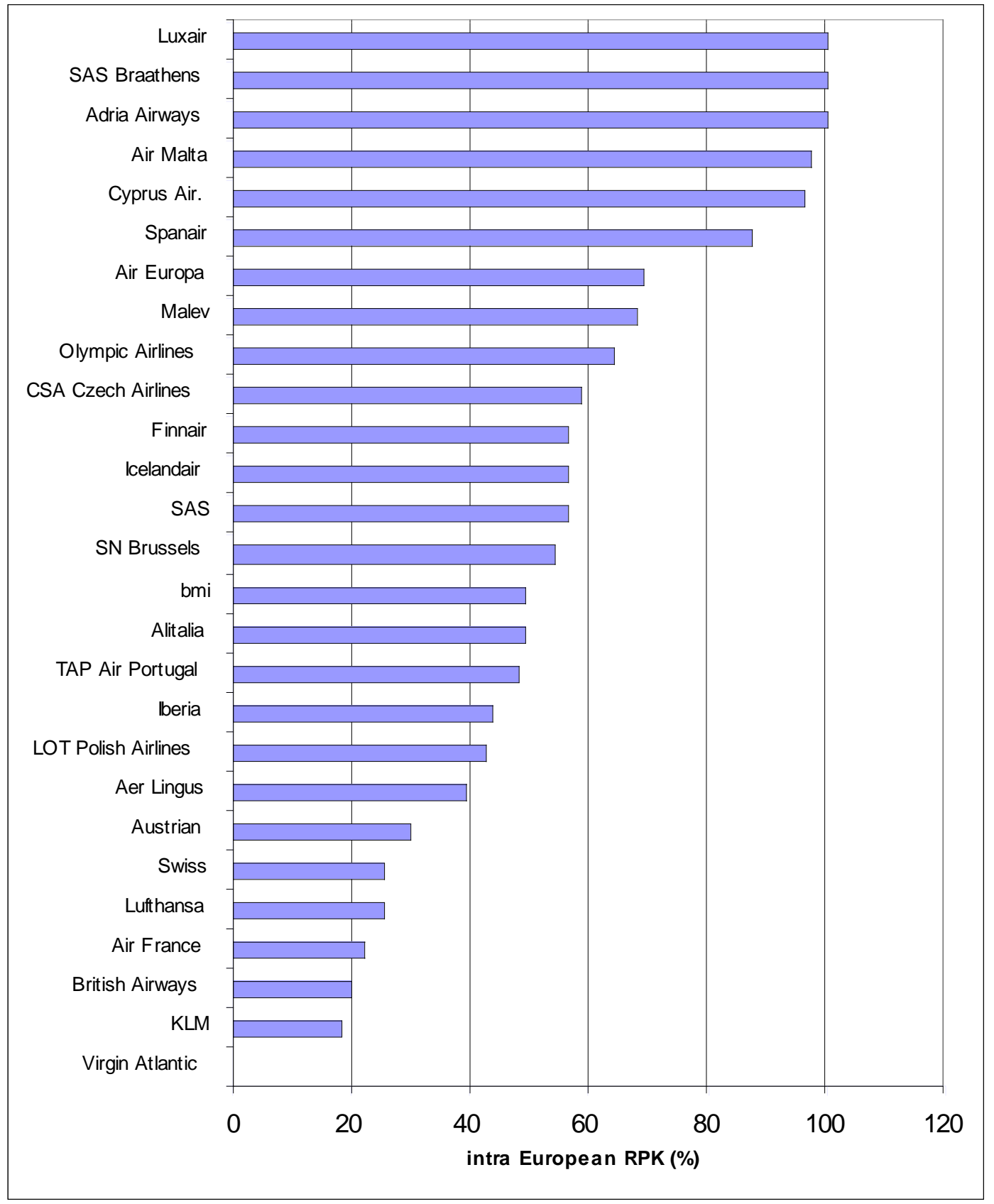

Source: IATA, 2005 
Table 2: Largest European Low cost carriers, by share of Low cost airline ASK

\begin{tabular}{lcc}
\hline & \% of total ASK & $\begin{array}{c}\text { Cumulative \% } \\
\text { of total EU low cost airlines }\end{array}$ \\
\hline Ryanair & 26 & 26 \\
easyJet & 24 & 50 \\
Air Berlin & 14 & 64 \\
Volare Airlines & 6 & 69 \\
bmibaby & 4 & 74 \\
Germanwings & 4 & 77 \\
Hagag-Lloyd Express & 3 & 81 \\
Virgin Express & 3 & 84 \\
flybe & 3 & 87 \\
Norwegian Air Shuttle & 3 & 89 \\
\hline
\end{tabular}

Source: OAG June 2004 
Figure 3: Percentage of seats provided by LCCs on domestic and intra-EU routes

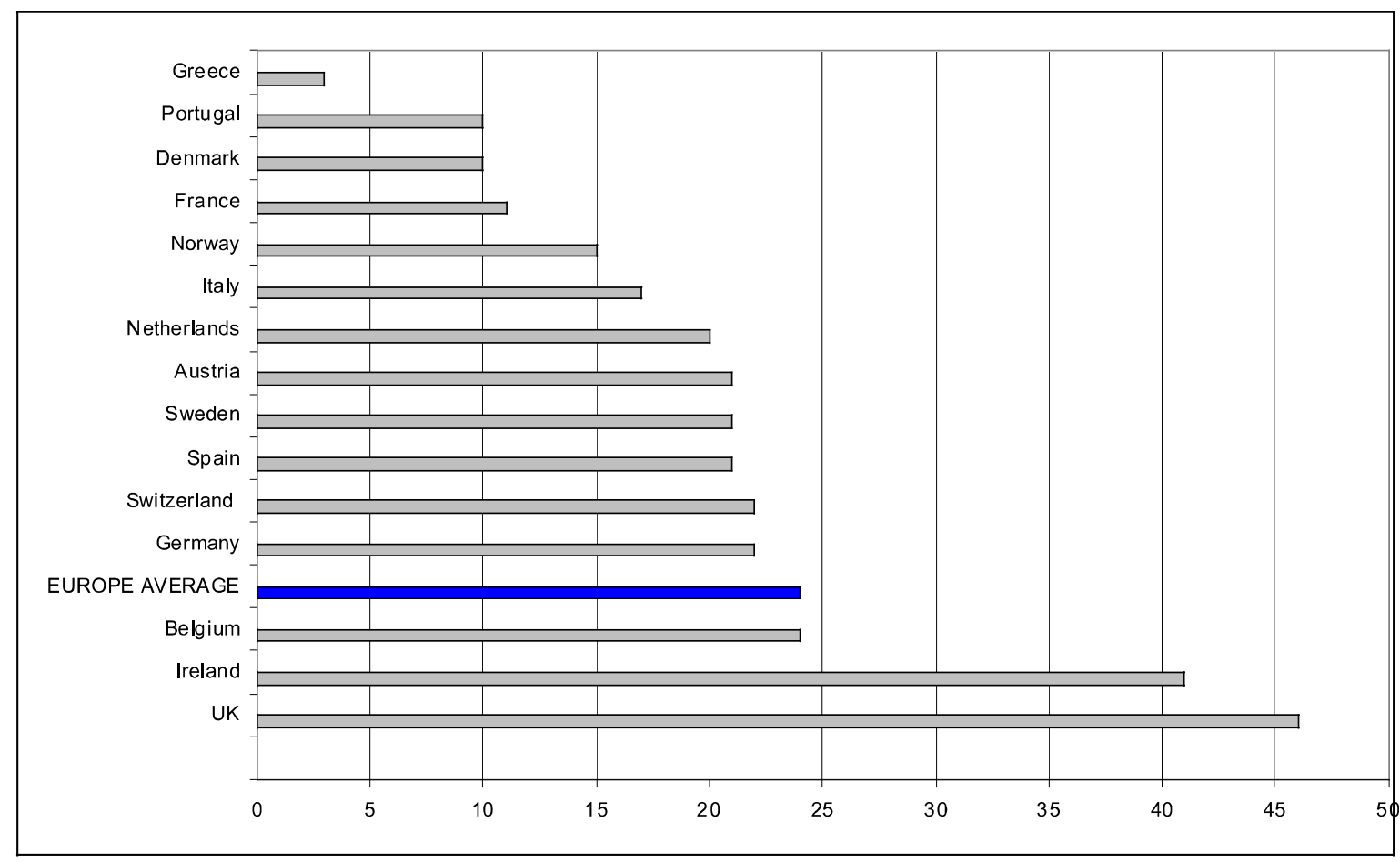

Source: compiled from OAG data (2005) 
Table 3: Scheduled passengers ex-UK airports by purpose of travel

\begin{tabular}{|c|c|c|c|c|c|c|c|c|}
\hline \multirow[b]{2}{*}{ Destination } & \multicolumn{2}{|c|}{2003 Passengers } & \multicolumn{2}{|c|}{1996 Passengers } & \multicolumn{2}{|c|}{$\begin{array}{c}\text { Annual \% growth } \\
1996 \text { - } 2003\end{array}$} & \multirow{2}{*}{$\begin{array}{c}\text { Leisure } \\
\text { share } \\
1996\end{array}$} & \multirow{2}{*}{$\begin{array}{c}\text { Leisure } \\
\text { share } \\
2003\end{array}$} \\
\hline & Business & Leisure & Business & Leisure & Business & Leisure & & \\
\hline Austria & 315,357 & 782,086 & 307,545 & 513,818 & 0.36 & 6.19 & $62.6 \%$ & $71.3 \%$ \\
\hline Belgium & 856,444 & 728,307 & 992,136 & 577,808 & -2.08 & 3.36 & $36.8 \%$ & $46.0 \%$ \\
\hline Denmark & 720,890 & $1,077,308$ & 631,075 & 718,399 & 1.92 & 5.96 & $53.2 \%$ & $59.9 \%$ \\
\hline Finland & 254,223 & 250,375 & 216,752 & 226,525 & 2.30 & 1.44 & $51.1 \%$ & $49.6 \%$ \\
\hline France & $2,328,962$ & $5,029,358$ & $2,098,315$ & $2,822,137$ & 1.50 & 8.60 & $57.4 \%$ & $68.3 \%$ \\
\hline Germany & $3,323,932$ & $4,916,891$ & $2,933,951$ & $3,380,707$ & 1.80 & 5.50 & $53.5 \%$ & $59.7 \%$ \\
\hline Luxembourg & 82,690 & 72,928 & 106,668 & 54,178 & -3.57 & 4.34 & $33.7 \%$ & $46.9 \%$ \\
\hline Netherlands & $1,967,767$ & $2,446,149$ & $1,656,336$ & $1,756,224$ & 2.49 & 4.85 & $51.5 \%$ & $55.4 \%$ \\
\hline Portugal & 384,056 & $1,397,200$ & 314,238 & 677,386 & 2.91 & 10.90 & $68.3 \%$ & $78.4 \%$ \\
\hline Spain & $1,581,031$ & $7,522,923$ & 873,923 & $2,182,573$ & 8.84 & 19.34 & $71.4 \%$ & $82.6 \%$ \\
\hline Sweden & 642,887 & $1,242,262$ & 625,562 & 605,603 & 0.39 & 10.81 & $49.2 \%$ & $65.9 \%$ \\
\hline Switzerland & $1,309,332$ & $2,076,950$ & $1,078,062$ & $1,409,122$ & 2.82 & 5.70 & $56.7 \%$ & $61.3 \%$ \\
\hline Total & $14,162,671$ & $28,243,490$ & $11,929,660$ & $15,076,150$ & 2.48 & 9.38 & $55.8 \%$ & $66.6 \%$ \\
\hline
\end{tabular}

(Incl. LCY, LGW, LHR, LTN, MAN, STN) 
Figure 4: Decline of intra European business class passengers (2001 - 2003)

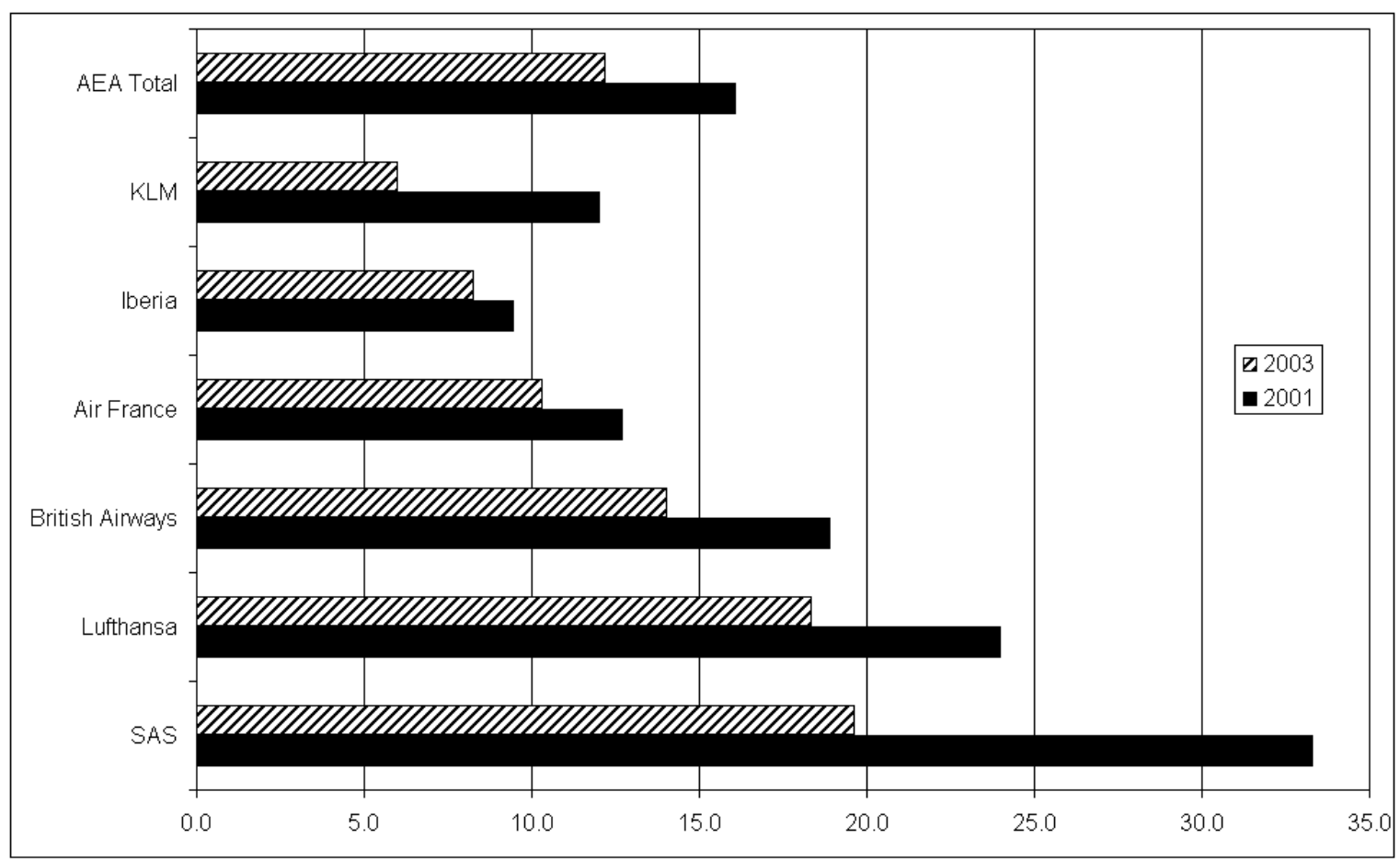

Source: Association of European Airlines, 2004 
Table 4: Business travel behaviour and attitudes

\begin{tabular}{|c|c|c|c|c|c|c|c|}
\hline $\begin{array}{l}\text { Traveller behaviour and } \\
\text { attitudes }\end{array}$ & $1998 / 99$ & $1999 / 2000$ & $2000 / 2001$ & $2001 / 2002$ & $2002 / 2003$ & $2003 / 2004$ & $2004 / 2005$ \\
\hline \multicolumn{8}{|l|}{ Use low cost airlines for } \\
\hline business travel? & $28 \%$ & $39 \%$ & $53 \%$ & $62 \%$ & - & $69 \%$ & $71 \%$ \\
\hline \multicolumn{8}{|l|}{$\begin{array}{l}\text { Percentage of annual } \\
\text { business travel in Business }\end{array}$} \\
\hline \multicolumn{8}{|l|}{ In general do you think } \\
\hline $\begin{array}{l}\text { Business Class provides } \\
\text { value for money? }\end{array}$ & \multicolumn{4}{|c|}{ Business Class provides } & & & \\
\hline Yes & $24 \%$ & $25 \%$ & $24 \%$ & $37 \%$ & - & $15 \%$ & - \\
\hline
\end{tabular}

Source: Company Barclaycard, Business Travel Survey (1999 - 2005) 
Figure 5: Factors influencing carrier choice (2004)

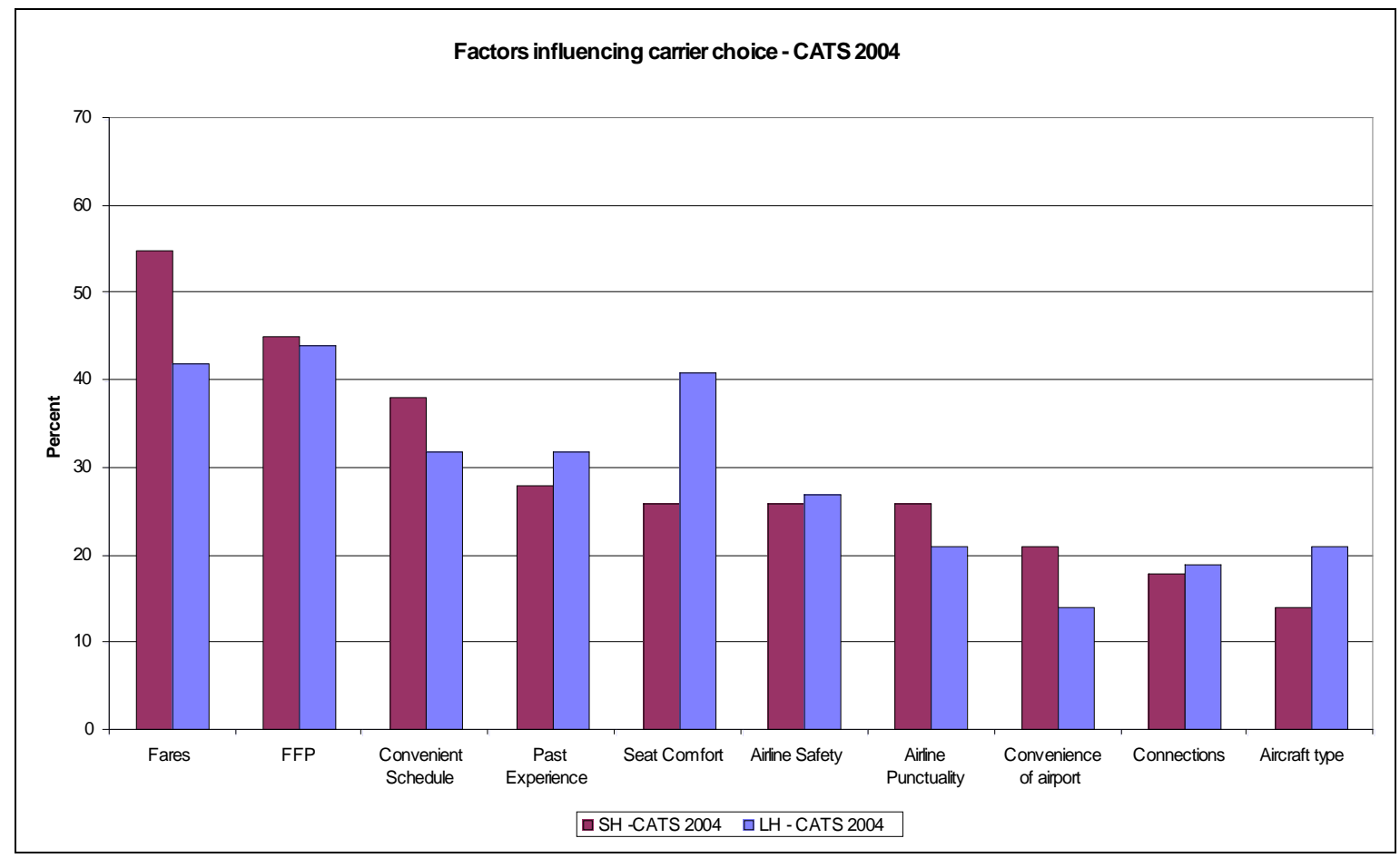

Source: Corporate Air Travel Survey, IATA, 2004 
Table 5: Paid holiday in major European countries (2003)

\begin{tabular}{lccc}
\hline & $\begin{array}{c}\text { Paid } \\
\text { holidays }\end{array}$ & $\begin{array}{c}\text { Total holidays } \\
\text { including public holidays }\end{array}$ & $\begin{array}{c}\text { \% of population taking a } \\
\text { holiday }\end{array}$ \\
\hline Germany & 25 & 45 & $75 \%$ \\
France & 25 & 47 & $74 \%$ \\
UK & 20 & 40 & $73 \%$ \\
Spain & 20 & 44 & $50 \%$ \\
Italy & 27 & 39 & $90 \%$ \\
Czech Republic & 15 & 34 & $83 \%$ \\
Poland & 15 & 34 & $56 \%$ \\
\hline
\end{tabular}

Source: Euromonitor, various country reports 
Table 6: Leisure trips by length of stay - average annual percentage growth (1999 - 2003)

\begin{tabular}{lccc}
\hline & $\mathbf{1 - 3}$ days & $\mathbf{4 - 7}$ days & More than $\mathbf{7}$ days \\
\hline Germany & -0.6 & -1.4 & 1.5 \\
France & 2.4 & 29.3 & -15.2 \\
UK & -0.3 & 0.3 & 0.2 \\
Spain & 1.7 & 1.6 & 0.3 \\
Italy & 4.4 & 2.3 & 1.3 \\
\hline Source: Euromonitor, various country reports & &
\end{tabular}

Source: Euromonitor, various country reports 
Table 7: First Stage Delphi Results: Network carriers

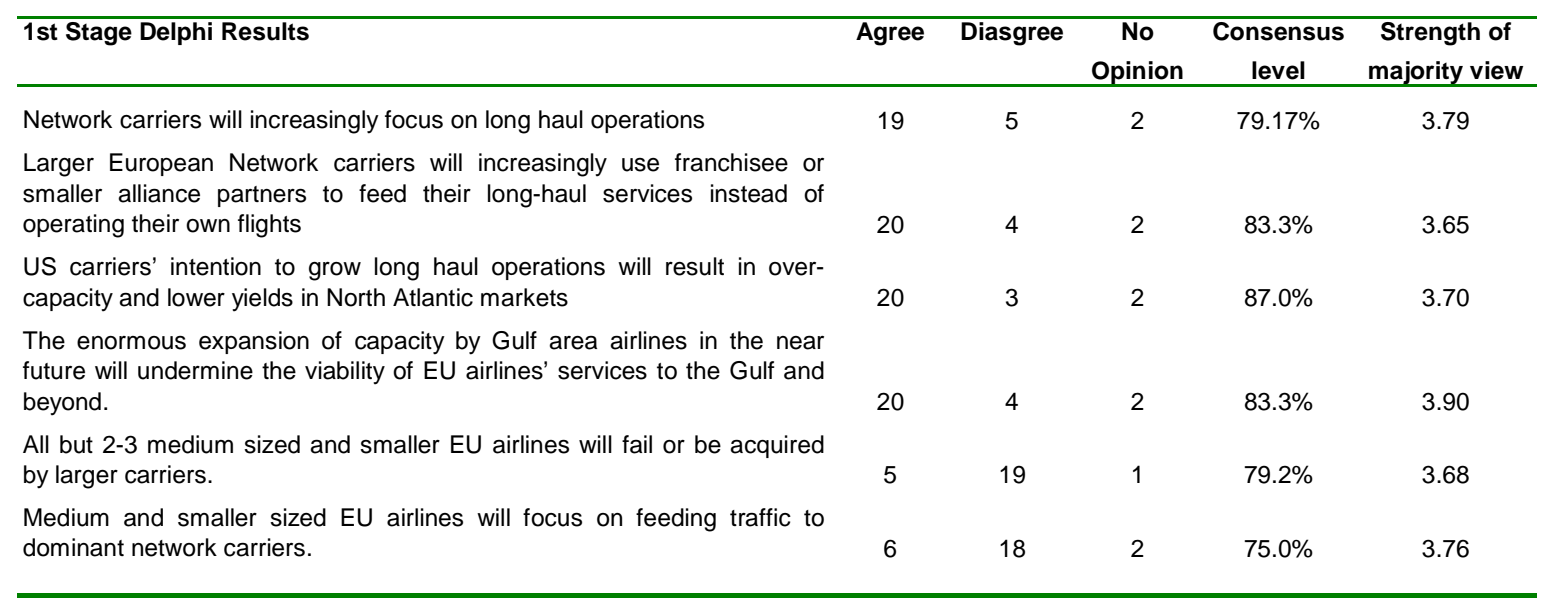

Strength of views measured from 1 (very weak) to 5 (very strong) 
Table 8: Second Stage Delphi Results: Network Carriers

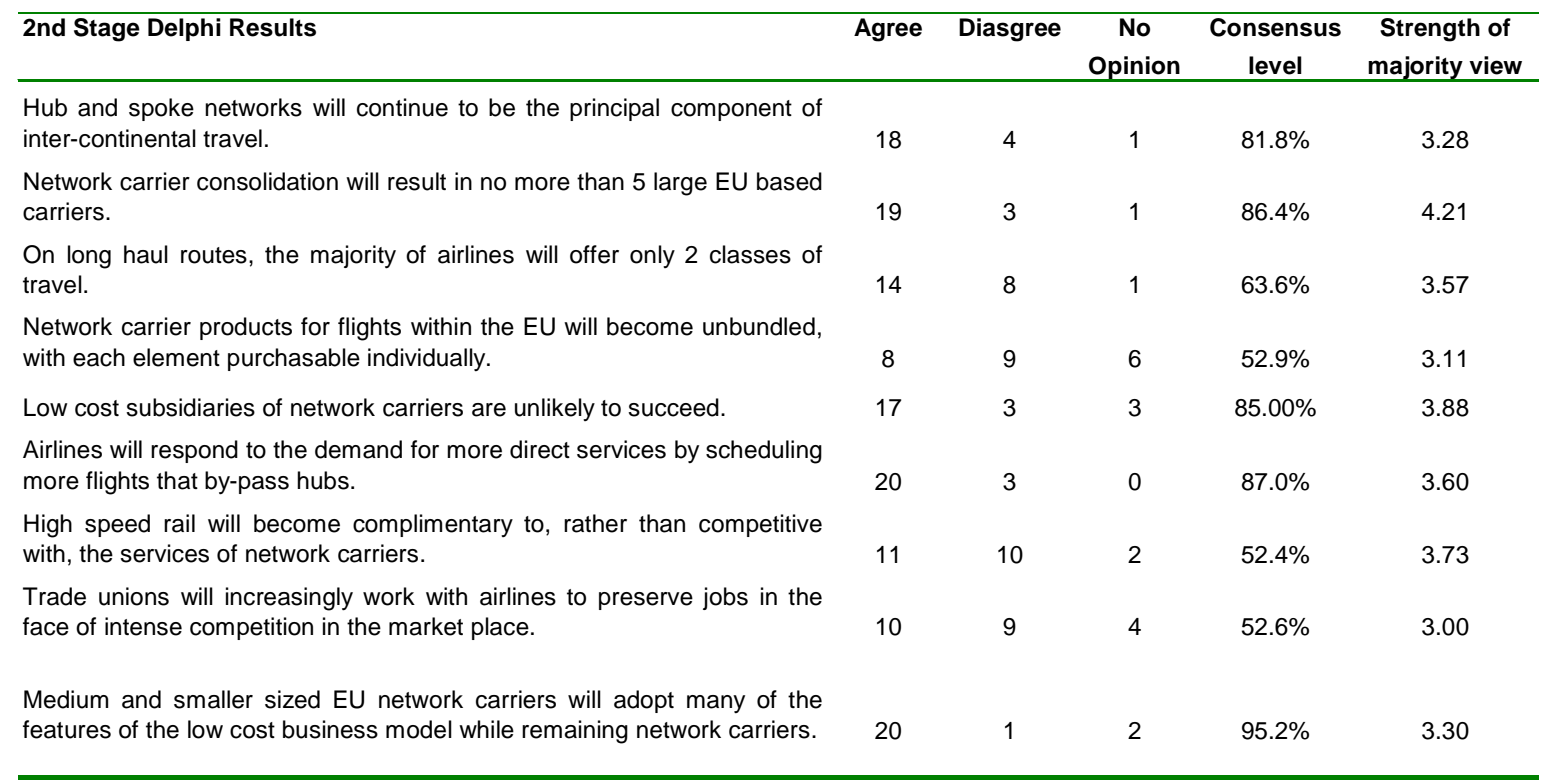


Table 9: First Stage Delphi Results: Low cost carriers

\begin{tabular}{|c|c|c|c|c|c|}
\hline 1st Stage Delphi Results & Agree & Diasgree & $\begin{array}{c}\text { No } \\
\text { Opinion }\end{array}$ & $\begin{array}{l}\text { Consensus } \\
\text { level }\end{array}$ & $\begin{array}{l}\text { Strength of } \\
\text { majority view }\end{array}$ \\
\hline $\begin{array}{l}\text { More than half of intra-EU traffic will be carried by low } \\
2015 \text {. }\end{array}$ & 18 & 5 & 2 & $78.3 \%$ & 3.78 \\
\hline There will be only 2-3 large EU low cost carriers by 2015 . & 19 & 4 & 2 & $82.61 \%$ & 3.63 \\
\hline
\end{tabular}


Table 10: Second Stage Delphi Results: Low cost carriers

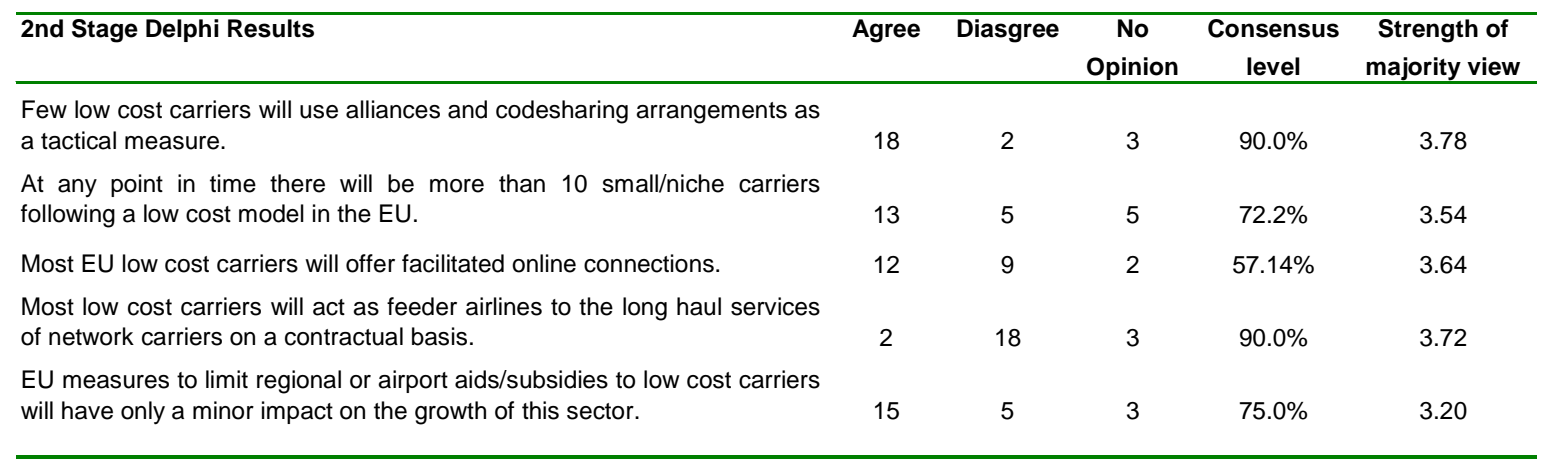


Table 11: First Stage Delphi Results: Market behaviour

\begin{tabular}{|c|c|c|c|c|c|}
\hline 1st Stage Delphi Results & Agree & Diasgree & $\begin{array}{c}\text { No } \\
\text { Opinion }\end{array}$ & $\begin{array}{l}\text { Consensus } \\
\text { level }\end{array}$ & $\begin{array}{l}\text { Strength of } \\
\text { majority view }\end{array}$ \\
\hline $\begin{array}{l}\text { As business travellers downgrade, business class travel products will no } \\
\text { longer be provided on the short haul market }\end{array}$ & 21 & 5 & 0 & $80.8 \%$ & 3.62 \\
\hline $\begin{array}{l}\text { The development of video conferencing technology will limit the growth of } \\
\text { air travel. }\end{array}$ & 0 & 25 & 1 & $100.0 \%$ & 3.88 \\
\hline $\begin{array}{l}\text { The trend for multiple short-duration holidays by air will continue to growth } \\
\text { over the next } 10 \text { years }\end{array}$ & 24 & 1 & 1 & $96.0 \%$ & 4.25 \\
\hline
\end{tabular}


Table 12: Second Stage Delphi Results: Market behaviour

\begin{tabular}{|c|c|c|c|c|c|}
\hline 2nd Stage Delphi Results & Agree & Diasgree & $\begin{array}{c}\text { No } \\
\text { Opinion }\end{array}$ & $\begin{array}{c}\text { Consensus } \\
\text { level }\end{array}$ & $\begin{array}{c}\text { Strength of } \\
\text { majority view }\end{array}$ \\
\hline $\begin{array}{l}\text { Business class only services, such as Lufthansa's Dusseldorf-New York } \\
\text { service, will be introduced and will succeed on only a limited number of } \\
\text { inter-continental routes. }\end{array}$ & 22 & 0 & 1 & $100.0 \%$ & 3.82 \\
\hline $\begin{array}{l}\text { For Europeans, long haul holiday markets will grow faster than those of } \\
\text { short haul. }\end{array}$ & 12 & 8 & 3 & $60.0 \%$ & 3.67 \\
\hline
\end{tabular}

